\title{
Identification Of Inhibiting Factors for Road Construction Using Sem Application In Kaway XVI Sub-District
}

\author{
Muhammad Isya $^{1 *}$, Meidia Refiyanni² ${ }^{2}$ Muhajir $^{2}$ \\ ${ }^{1}$ Faculty of Engineering, Syiah Kuala University, Aceh Indonesia \\ ${ }^{2}$ Faculty of Engineering, Teuku Umar University, Aceh Indonesia \\ *Corresponding author E-mail:m_isya@unsyiah.ac.id
}

Manuscript received 15 August 2021; revised 1 Sept 2021; accepted 15 Sept 2021. Date of publication 4 Nov 2021

\begin{abstract}
Road construction is one thing that is always in line with technological advances and human thinking. Because the road is an important facility for humans, in order to reach an area. Continuous use of the road will reduce the service life of the road to the economic life of the road. To restore the service condition of the road, it is necessary to carry out road maintenance. Kaway XVI Sub-district is one of the connecting lines for Pidie Regency - West Aceh Regency, the road will continue to be built and maintained to support the agricultural and fishery sectors. The purpose of this study was to identify the inhibiting factors for road construction and maintenance as well as the relationship between these factors and indicators in Kaway XVI District using Structural Equation Modeling (SEM). The results of the study indicate that the quality factor has a positive effect on Spatial Planning and the Environment (TRL), and financing with a correlation number of 0.25 and 0.17. Regulations and Policies (PK) have a positive effect on financing of 0.60. Quantity has a positive effect on politics with a correlation number of 0.07 . Politics has a positive effect on Regulations and Policies (PK) with a correlation number of 0.73, but negatively on TRL with a correlation number of -0.09. TRL has a positive effect on Human Resources (HR) with a correlation number of 0.81 . HR has a significant positive effect on politics with a correlation of 0.67 . Based on the research path diagram, the most decisive indicators both in quality and quantity for the construction and maintenance of roads in support of the Agriculture and Fisheries Sector are TRL, Financing, Politics and PK.
\end{abstract}

\section{Keywords: Construction, Maintenance, Road, SEM, AMOS.}

\section{Introduction}

The mode of transportation that plays an important role as infrastructure is the road [1]. In addition, the road also functions as an access or path used for activities. Socio-economic growth between regions is highly dependent on land transportation infrastructure [2]. The driving wheel of economic growth is an integral part of national development called infrastructure development [3]. Meanwhile, the condition of road infrastructure in Indonesia is also still low compared to other countries. Road infrastructure development refers to spatial planning, and the National Transportation System (SISTRANAS). Road infrastructure development must consider several aspects, namely: economic aspects, social aspects and environmental aspects [4].

Development can improve the standard of living and welfare of the people, therefore development is the will of the people. However, public understanding of development is needed so that optimal development can be achieved. To realize the development is not entirely the responsibility of the government but it needs community participation [5]. Road infrastructure development is a driver of national economic growth as well as inter-regional connectivity [6]. One indicator to measure the economic performance of a country is through economic growth [7]. In addition, road infrastructure development projects have a high risk when compared to other construction projects, this is due to the importance of a country's economic growth [8]. If the infrastructure is bad, it will have an impact on one of the community activities, namely farmers, in bringing crops [9]. Improving the quality of life and human well-being depends on infrastructure. road [10]. Road infrastructure has an important role in increasing investment. So that it becomes a driving force for economic growth.

Continuous use of the road will result in a decrease in the service life up to the economic life of the road. To restore the condition of the service period, it is necessary to maintain roads and improve roads. Road improvement can be in the form of increasing the road pavement structure and also widening the road to increase road capacity. In Indonesia, road maintenance has been regulated in laws and regulations such as Law no. 38 of 2004 concerning roads, Government Regulation no. 34 of 2006 concerning roads, Law No. 22 of 2009 
concerning Road Traffic and Transportation, RUNK (National General Safety Plan), the Directorate General of Highways, and the Ministry of Public Works [4].

West Aceh Regency is one of the regencies in Aceh Province which is geographically located in the South West coast region. Each side of the area is directly adjacent to the ocean and mountains. West Aceh Regency which has 12 sub-districts, one of which is Kaway XVI District. Kaway XVI sub-district is the Tutut - Meulaboh crossing which supports the agricultural and fishery sectors.

\section{Literature Review}

The development of a region depends on the development of the region. The potential of a region is part of the development of the region. If the regional development is not touched, there will be no development and progress of the region[13]. Structural Equation Modeling (SEM) is a statistical modeling technique used to analyze the independent variables that are correlated with several latent independent variables, each of which is measured by many indicators. [14]. Structural Equation Modeling (SEM) analysis is a multivariate analysis, which shows a degree of causal relationship in a path diagram [15]. The model fit index is a step in determining a model. To determine whether or not a model is accepted, it must be tested for the degree of fit (Goodness of Fit)[16].

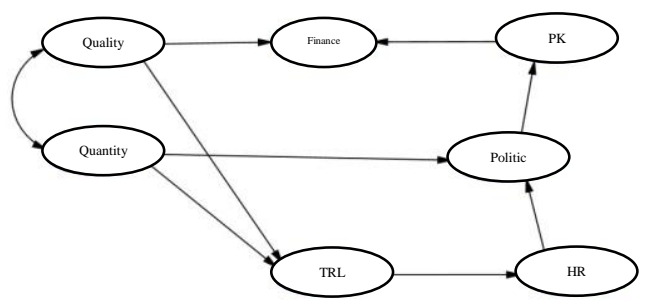

Fig 1. Theoretical Framework Model/Pathdiagram

The data processing technique used is the Confirmatory Analysis (CFA) method. The CFA method is a measurement model in which the variables (indicators) are one particular variable (Latent Dimension) [16].

\section{Methods}

The variables in this study include 7 (seven) variables, namely: Quantity, Quality, Financing, Regulations and policies, Politics and Human Resources (HR), and Spatial Planning and Environment (TRL) with 24 indicators. To obtain interval data, all indicators are measured using a Likert scale.

Table 1. Skala Likert 1

\begin{tabular}{clc}
\hline No. & \multicolumn{1}{c}{ Statement } & Skor \\
\hline 1. & Very Unsteady (STM) & 1 \\
\hline 2. & Unsteady (TM) & 2 \\
\hline 3. & Steady $(\mathrm{M})$ & 3 \\
\hline 4. & Very Steady (SM) & 4 \\
\hline
\end{tabular}

Table 2. Skala likert 2

\begin{tabular}{clc}
\hline No. & \multicolumn{1}{c}{ Statement } & Skor \\
\hline 1. & Very Inadequate $($ STM) & 1 \\
\hline 2. & Inadequate $($ STM) & 2 \\
\hline 3. & Adequate $(\mathrm{M})$ & 3 \\
\hline 4. & Very Adequate $(\mathrm{SM})$ & 4 \\
\hline
\end{tabular}

Table 3. Skala likert 3

\begin{tabular}{clc}
\hline No. & \multicolumn{1}{c}{ Statement } & Skor \\
\hline 1. & Very Inadequate $(\mathrm{STM})$ & 1 \\
\hline 2. & Inadequate $(\mathrm{STM})$ & 2 \\
\hline 3. & Adequate $(\mathrm{M})$ & 3 \\
\hline 4. & Very Adequate $(\mathrm{SM})$ & 4 \\
\hline
\end{tabular}

\section{Types and Sources of Data}

\section{Primary Data}

Primary data was obtained through direct visual observation at the research location in the form of observation data and questionnaires to related parties and the community.

2. Secondary Data

The secondary data used in this study are a map of Aceh Province, a map of West Aceh Regency and a map of Kaway XVI District. This data was obtained from the National Disaster Management Agency (BNPB) and the Department of Public Works and Spatial Planning (PUPR) of West Aceh Regency. 


\section{Analysis and Processing Data}

1. Development of theory-based models

2. Development of flowcharts to show causality

3. Convert flowcharts into a series of equations

4. Selection of the input data matrix and estimating the proposed model

5. Assess the possibility of identification problems

6. Structural Model Evaluation

7. Interpret and Modify the Model.

\section{Model Fit Index}

The level of fit of the selected model must be seen from the Goodness of Fit (degree of fit) and the significant coefficients on the measurement model and the structural model of the model. The degree of this match can be seen in table 4 below:

Table 4. Goodness of Fit Indices

\begin{tabular}{cc}
\hline Goodness of Fit Indices & Cut Off - Value \\
\hline $\mathrm{X}^{2}$ Chi-Square & Diharapkan Kecil \\
\hline Probabilitas & $\geq 0,05$ \\
\hline CMIN/DF & $\leq 2,00$ \\
\hline RMSEA & $\leq 0,08$ \\
\hline GFI & $\geq 0,90$ \\
\hline AGFI & $\geq 0,90$ \\
\hline TLI & $\geq 0,95$ \\
\hline CFI & $\geq 0,95$
\end{tabular}

\section{Results and Discussion}

\section{Validity test}

Validation test is needed to find out whether the indicators on the questionnaire form are valid or not, based on the data for the answers received from all respondents, where the value of $\mathrm{R}$ count $>\mathrm{R}$ table. Valid means that the indicator stated by the respondent at the research location is correct, by connecting the Degree of Free down (DF) value to the two-way option at an error level of 5\% (0.05). The R table value for 200 samples is 0.138 . The results of the validation test using IBM SPSS statistics 22 software can be seen in table 4 . below:

Table 5. Validity test

\begin{tabular}{|c|c|c|c|c|}
\hline Factor & $\begin{array}{c}\text { Code } \\
\text { Indicator }\end{array}$ & $\mathrm{R}_{\text {Count }}$ & $\mathrm{R}$ Table & Information \\
\hline \multirow[t]{3}{*}{ Road Quality (Y) } & Y1 & 0,394 & \multirow[t]{3}{*}{0,138} & \multirow[t]{3}{*}{ Valid } \\
\hline & Y2 & 0,424 & & \\
\hline & Y3 & 0,384 & & \\
\hline Road Quantity (Y) & Y4 & 0,210 & 0,138 & Valid \\
\hline \multirow[t]{2}{*}{ Financing $\left(\mathrm{X}_{1}\right)$} & $\mathrm{X} 1.1$ & 0,459 & \multirow{2}{*}{0,138} & \multirow[t]{2}{*}{ Valid } \\
\hline & $\mathrm{X} 1.2$ & 0,542 & & \\
\hline \multirow{3}{*}{$\begin{array}{l}\text { Regulations and Poli- } \\
\text { cies (X2) }\end{array}$} & $\mathrm{X} 2.1$ & 0,639 & \multirow[t]{3}{*}{0,138} & \multirow[t]{3}{*}{ Valid } \\
\hline & $\mathrm{X} 2.2$ & 0,594 & & \\
\hline & $\mathrm{X} 2.3$ & 0,624 & & \\
\hline \multirow[t]{6}{*}{ Politic (X3) } & $\mathrm{X} 3.1$ & 0,539 & \multirow[t]{6}{*}{0,138} & \multirow[t]{6}{*}{ Valid } \\
\hline & $\mathrm{X} 3.2$ & 0,575 & & \\
\hline & X3.3 & 0,527 & & \\
\hline & X3.4 & 0,607 & & \\
\hline & X3.5 & 0,589 & & \\
\hline & X3.6 & 0,607 & & \\
\hline \multirow{4}{*}{$\begin{array}{l}\text { Human } \\
\text { (X4) }\end{array}$} & $\mathrm{X} 4.1$ & 0,683 & \multirow[t]{4}{*}{0,138} & \multirow[t]{4}{*}{ Valid } \\
\hline & $\mathrm{X} 4.2$ & 0,664 & & \\
\hline & $\mathrm{X} 4.3$ & 0,643 & & \\
\hline & $\mathrm{X} 4.4$ & 0,652 & & \\
\hline \multirow{9}{*}{$\begin{array}{l}\text { Spatial Planning and } \\
\text { Environment (TRL) }\end{array}$} & X5.1 & 0,632 & \multirow[t]{9}{*}{0,138} & \multirow[t]{9}{*}{ Valid } \\
\hline & $\mathrm{X} 5.2$ & 0,647 & & \\
\hline & X5.3 & 0,602 & & \\
\hline & X5.4 & 0,610 & & \\
\hline & X5.5 & 0,548 & & \\
\hline & X5.2 & 0,647 & & \\
\hline & X5.3 & 0,602 & & \\
\hline & X5.4 & 0,610 & & \\
\hline & X5.5 & 0,548 & & \\
\hline
\end{tabular}




\section{Reliability Test}

Reliability test is used to find out whether the existing variables are reliable or not, based on filling in the answers received from all respondents. Reliable is an indicator that is in a variable as a whole will reflect the variable itself. The following is a reliable test value:

Table 6. Reliability Test

\begin{tabular}{|c|c|c|c|}
\hline No. & Indicator & Cronbach's Alpha $>0,6$ & Information \\
\hline 1 & y1 & 0,903 & Reliable \\
\hline 2 & y2 & 0,903 & Reliable \\
\hline 3 & y3 & 0,904 & Reliable \\
\hline 4 & y4 & 0,907 & Reliable \\
\hline 5 & $\mathrm{x} 1.1$ & 0,902 & Reliable \\
\hline 6 & $\mathrm{x} 1.2$ & 0,900 & Reliable \\
\hline 7 & $\mathrm{x} 2.1$ & 0,898 & Reliable \\
\hline 8 & $\mathrm{x} 2.2$ & 0,899 & Reliable \\
\hline 9 & $\mathrm{x} 2.3$ & 0,898 & Reliable \\
\hline 10 & $\mathrm{x} 3.1$ & 0,900 & Reliable \\
\hline 11 & $\mathrm{x} 3.2$ & 0,899 & Reliable \\
\hline 12 & $\mathrm{x} 3.3$ & 0,901 & Reliable \\
\hline 13 & $\mathrm{x} 3.4$ & 0,898 & Reliable \\
\hline 14 & $\mathrm{x} 3.5$ & 0,899 & Reliable \\
\hline 15 & $\mathrm{x} 3.6$ & 0,898 & Reliable \\
\hline 16 & $\mathrm{x} 4.1$ & 0,897 & Reliable \\
\hline 17 & $\mathrm{x} 4.2$ & 0,897 & Reliable \\
\hline 18 & $\mathrm{x} 4.3$ & 0,898 & Reliable \\
\hline 19 & $\mathrm{x} 4.4$ & 0,898 & Reliable \\
\hline 20 & $\mathrm{x} 5.1$ & 0,898 & Reliable \\
\hline 21 & $\mathrm{x} 5.2$ & 0,898 & Reliable \\
\hline 22 & $\mathrm{x} 5.3$ & 0,899 & Reliable \\
\hline 23 & $\mathrm{x} 5.4$ & 0,898 & Reliable \\
\hline 24 & $\mathrm{x} 5.5$ & 0,900 & Reliable \\
\hline
\end{tabular}

\section{Theory-Based Model Development}

After the preparation of the theory-based model, it is continued with a causality diagram from the theoretical study that has been made, with the aim of knowing the causal relationship between factors and indicators that have been set.

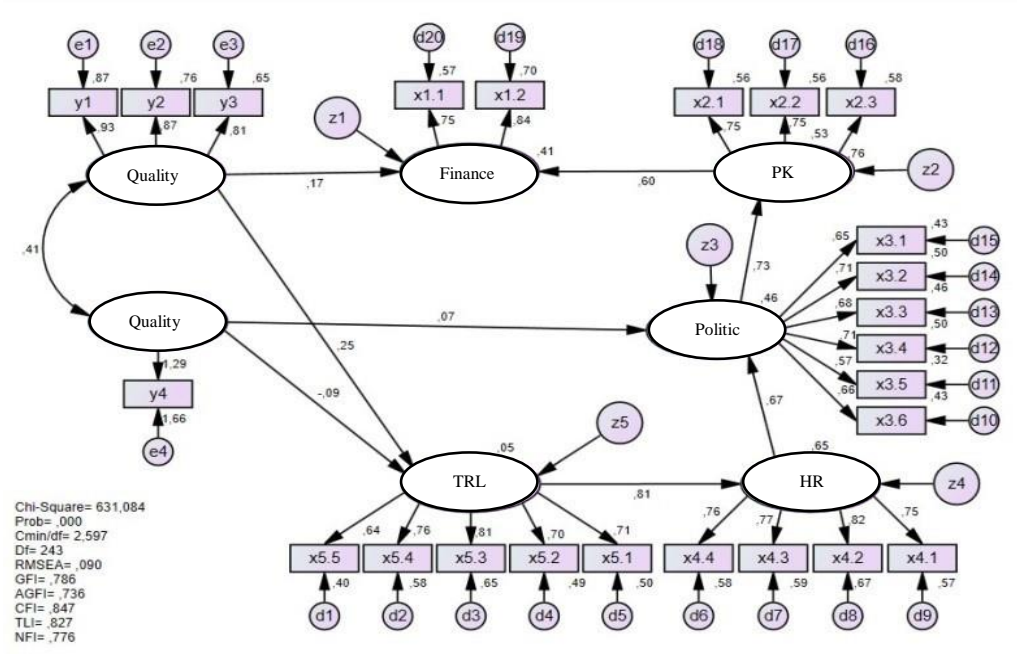

Fig 2. Model Pathdiagram hubungan kausalitas 
The estimation technique used in this study is maximum likelihood (ML), the estimation method that has become the default of this program. Estimation is carried out in 2 stages, namely :

Measurement Model (Confirmatory Factor Analysis/CFA)

This technique is to estimate the measure model to test the unidimensionality of exogenous constructs and endogenous constructs. There are 4 tests that use Confirmatory Factor Analysis (CFA) :

a. Model Fit Test (Goodness of Fit Test)

\begin{tabular}{cccl}
\hline $\begin{array}{c}\text { Goodness of Fit } \\
\text { Indices }\end{array}$ & $\begin{array}{c}\text { Table 7. Model Test and Cut Off Value } \\
\text { Results }\end{array}$ & Cut Of Value & Information \\
\hline $\mathrm{X}^{2}$ Chi-Square & 631,084 & Small $^{*}$ & Fit Model \\
\hline Probabilitas & 0,000 & $\geq 0,05$ & Model not fit \\
\hline CMIN/DF & 2,597 & $\leq 2,00$ & Model not fit \\
\hline RMSEA & 0,090 & $\leq 0,08$ & Model not fit \\
\hline GFI & 0,786 & $\geq 0,90$ & Model not fit \\
\hline AGFI & 0,736 & $\geq 0,90$ & Marginal \\
\hline TLI & 0,847 & $\geq 0,95$ & Marginal \\
\hline CFI & 0,776 & $\geq 0,95$ & Fit Model \\
\hline
\end{tabular}

\section{b. Convergent Validation Test}

Table 8. Regression Weight Measurement Model Test

\begin{tabular}{|c|c|c|c|c|c|c|c|}
\hline & & & $\begin{array}{c}\text { Estimat } \\
\mathrm{e}\end{array}$ & S.E. & C.R. & $\mathrm{P}$ & $\begin{array}{c}\text { Standardize Reg. } \\
\text { weight }(\lambda)\end{array}$ \\
\hline TRL & $<--$ & quality & 0,191 & 0,093 & 2,060 & 0,039 & 0,251 \\
\hline TRL & $<---$ & quantity &,- 050 & 0,120 &,- 414 & 0,679 &,- 093 \\
\hline HR & $<---$ & TRL & 0,871 & 0,103 & 8,413 & 0,000 & 0,809 \\
\hline Politic & $\begin{array}{l}<-- \\
\end{array}$ & HR & 0,590 & 0,087 & 6,825 & 0,000 & 0,675 \\
\hline Politik & $<--$ & quantity & 0,036 & 0,079 &, 457 & 0,647 & 0,071 \\
\hline PK & <--- & Politic & 0,879 & 0,122 & 7,202 & 0,000 & 0,731 \\
\hline Financing & $<---$ & quality & 0,153 & 0,068 & 2,233 & 0,026 & 0,173 \\
\hline Financing & $<---$ & PK & 0,614 & 0,098 & 6,243 & 0,000 & 0,601 \\
\hline y1 & $\begin{array}{l}<-- \\
\end{array}$ & quality & 1,000 & & & & 0,932 \\
\hline $\mathrm{y} 2$ & $\begin{array}{l}<-- \\
\end{array}$ & quality & 0,935 & 0,053 & 17,624 & 0,000 & 0,872 \\
\hline $\mathrm{y} 3$ & <--- & quality & ,916 & 0,059 & 15,407 & 0,000 & 0,809 \\
\hline $\mathrm{y} 4$ & <--- & quantity & 1,000 & & & & 1,289 \\
\hline $\mathrm{x} 1.1$ & <--- & Financing & 1,000 & & & & 0,753 \\
\hline $\mathrm{x} 1.2$ & $\begin{array}{l}<-- \\
\end{array}$ & Financing & 1,064 & 0,138 & 7,693 & 0,000 & 0,838 \\
\hline $\mathrm{x} 2.1$ & $<--$ & PK & 1,000 & & & & 0,749 \\
\hline $\mathrm{x} 2.2$ & <--- & $\mathrm{PK}$ & 1,019 & 0,107 & 9,560 & 0,000 & 0,750 \\
\hline $\mathrm{x} 2.3$ & $\begin{array}{l}<-- \\
\end{array}$ & PK & 1,036 & 0,121 & 8,558 & 0,000 & 0,763 \\
\hline x3.1 & $<---$ & Politic & 1,000 & & & & 0,652 \\
\hline x3.2 & <--- & Politic & 1,123 & 0,139 & 8,104 & 0,000 & 0,708 \\
\hline $\mathrm{x} 3.3$ & $<---$ & Politic & 1,123 & 0,135 & 8,291 & 0,000 & 0,682 \\
\hline x3.4 & <--- & Politic & 1,109 & 0,138 & 8,011 & 0,000 & 0,708 \\
\hline $\mathrm{x} 3.5$ & <--- & Politic & 0,935 & 0,140 & 6,660 & 0,000 & 0,570 \\
\hline x3.6 & $<---$ & Politic & 1,058 & 0,139 & 7,591 & 0,000 & 0,659 \\
\hline $\mathrm{x} 4.1$ & $<---$ & HR & 1,000 & & & & 0,755 \\
\hline $\mathrm{x} 4.2$ & $<---$ & $\mathrm{HR}$ & 1,046 & 0,089 & 11,811 & 0,000 & 0,821 \\
\hline $\mathrm{x} 4.3$ & $<---$ & $\mathrm{HR}$ & 1,010 & 0,097 & 10,375 & 0,000 & 0,767 \\
\hline $\mathrm{x} 4.4$ & $<---$ & HR & 0,919 & 0,090 & 10,167 & 0,000 & 0,760 \\
\hline $\mathrm{x} 5.1$ & <--- & TRL & 1,000 & & & & 0,706 \\
\hline $\mathrm{x} 5.2$ & <--- & TRL & 1,009 & 0,108 & 9,351 & 0,000 & 0,703 \\
\hline$\times 5.3$ & $<---$ & TRL & 1,127 & 0,116 & 9,675 & 0,000 & 0,806 \\
\hline$x 5.4$ & $<---$ & TRL & 1,130 & 0,126 & 8,980 & 0,000 & 0,765 \\
\hline$\times 5.5$ & $<---$ & TRL & 0,932 & 0,117 & 7,942 & 0,000 & 0,636 \\
\hline
\end{tabular}

To see the significant test, it is seen from the CR column with the provisions that the CR value 2.011 ( $\mathrm{t}$-table) is obtained from $\mathrm{df}=48$ and $=0.005$. To see the relationship between variables whether positive or negative can be seen in the Standardize Reg column. Weight $(\lambda)$ 


\section{Model Interpretation and Modification}

The model after the estimation has been carried out can still be modified to the developed model, if the model estimation results have a large residue. The following is the value of the relationship between variables.

Table 9. Relationship between variables

\begin{tabular}{llll}
\hline \multicolumn{2}{c}{ Relationship between variables } & Correlations \\
\hline Quality & $<-->$ & Quantity & 1,183 \\
\hline Quality & $<-->$ & TRL & 0,217 \\
\hline Quality & $<-->$ & TRL & 0,069 \\
\hline Quality & $<-->$ & PK & 0,232 \\
\hline Quality & $<-->$ & PK & 0,416 \\
\hline PK & $<-->$ & TRL & 0,438 \\
\hline Quality & $<-->$ & Politic & 0,109 \\
\hline Quantity & $<-->$ & Politic & 0,112 \\
\hline PK & $<-->$ & Politic & 0,765 \\
\hline Politic & $<-->$ & TRL & 0,534 \\
\hline Politic & $<-->$ & HR & 0,654 \\
\hline PK & $<-->$ & HR & 0,555 \\
\hline SDM & $<-->$ & TRL & 0,811 \\
\hline Quality & $<-->$ & HR & 0,145 \\
\hline Quantity & $<-->$ & HR &,- 160 \\
\hline
\end{tabular}

\section{Quality Has Positive Effect on Spatial Planning and Environment (TRL)}

The initial hypothesis (H1) proposed is that there is a positive effect of Quality on TRL with a correlation number of 0.25 . This means that the TRL factor is very much needed for Quality in terms of road construction and maintenance in Kaway XVI District to support the Agriculture and Fisheries sector. The initial hypothesis (H2) proposed is that there is a negative effect of Quantity on TRL with a correlation number of -0.09 . This means that the TRL factor is not sufficiently influential on the quantity of road construction and road maintenance in Kaway XVI District.

\section{TRL has a positive effect on HR}

The initial hypothesis $(\mathrm{H} 3)$ proposed is that there is a positive effect of TRL on HR with a correlation number of 0.81 . This means that the HR factor is very influential on spatial planning, the better the HR, the better the TRL.

\section{HR has a positive effect on politics}

The initial hypothesis (H4) proposed is that there is a positive influence of HR on politics with a correlation number of 0.67 . This means that political factors are very influential on the development and empowerment of human resources.

Kuantitas berpengaruh positif terhadap Politik

The initial hypothesis (H5) proposed is that there is a positive influence of Quantity on Politics with a correlation number of 0.07 . This means that political factors affect the quality of the road, by reducing politics, the quantity will be better.

\section{Politics has a positive effect on PK}

The initial hypothesis (H6) proposed is that there is a positive influence from Politics on PK with a correlation number of 0.73 . This means that political factors also greatly affect the PK, the better the politics, the better the PK for the process of road construction and maintenance in Kaway XVI District.

\section{Quality has a positive effect on Financing}

The initial hypothesis (H7) proposed is that there is a positive effect of Quality on Financing with a correlation number of 0.17 . This means that to achieve good road quality, adequate financing is needed.

\section{PK has a positive effect on financing}

The initial hypothesis (H8) proposed is that there is a positive effect of PK on financing with a correlation number of 0.60 . This means that financing for construction and maintenance will be very adequate if the PK is as expected.

\section{Conclusion}

The results showed that carried out with various tests of each indicator, the chi-square value was 631.084; probability value is 0.000 ; the value of CMIN/DF is 2,597; RMSEA value is 0.090; the GFI value is 0.786; AGFI value is 0.736 ; TLI value is 0.827 ; CFI value is 0.847 ; and the NFI value is 0.776 . The results of the pathdiagram model test show that there are two indices that the Model Fits, 2 marginal indices and 4 indeces that do not fit the model. So that the factors that influence the construction and maintenance of roads in supporting the agricultural and fishery sectors in Kaway XVI District are the Factors of Regulation and Policy (PK) on Politics of 0.879; followed by the factor of Human Resources (HR) on Spatial Planning and the Environment (TRL) of 0.871; and the Financing factor for Regulations and Policies (PK) of 0.614. 


\section{Acknowledgement}

Structural Equation Modeling (SEM) is a statistical modeling technique used to analyze the independent variables that are correlated with several latent independent variables, each of which is measured by many indicators.

\section{References}

[1] M. Refiyanni and C. S. Silvia, "Analisis Nilai Kondisi Jalan dan Kemantapan Jalan Sebagai Jalur Evakuasi," J. Tek. Sipil dan Teknol. Konstr., vol. 6, no. November, pp. 41-51, 2020, [Online]. Available: http://180.250.41.45/jtsipil/article/view/2746.

[2] J. Srianty, M. Isya, and R. Anggraini, "Analisis Kondisi Kemantapan Jalan Dengan Lalu Lintas Harian Rata-Rata Pada Jalan Arteri Sekunder,” J. Tek. Sipil Fak. Tek. Univ. Syiah Kuala, vol. Vol.1, no. No.1, pp. 99-110, 2017.

[3] H. Fidelia, "Analisis Faktor-Faktor Yang Menghambat Percepatan Pembangunan Infrastruktur Transportasi Di Daerah," 2010, [Online]. Available: http://lib.ui.ac.id/file?file=digital/2016-10/20248610-S50595-Helen Fidelia.pdf.

[4] P. Pelaksanaan and S. Jalan, “17 2010, No.606,” no. 606, pp. 17-97, 2010.

[5] J. Herman, "Implementasi Pembangunan Infrastruktur Dalam Rangka Percepatan Pembangunan Daerah di Kecamatan Sekolaq Darat Kabupaten Kutai Barat," eJournal Adm. Reform, vol. 3, no. 3, pp. 2281-2291, 2014.

[6] PUPR, “Informasi Statistik PUPR 2020,” pp. 1-108, 2019.

[7] T. Sukwika, "Peran Pembangunan Infrastruktur terhadap Ketimpangan Ekonomi Antarwilayah di Indonesia," J. Wil. dan Lingkung., vol. 6, no. 2, p. 115, 2018, doi: 10.14710/jwl.6.2.115-130.

[8] R. A. Rahman, A. R. Radzi, M. S. H. Saad, and S. I. Doh, "Factors affecting the success of highway construction projects: The case of Malaysia," IOP Conf. Ser. Mater. Sci. Eng., vol. 712, no. 1, 2020, doi: 10.1088/1757-899X/712/1/012030.

[9] C. Sasmito, "Implementasi Pembangunan Infrastruktur Jalan Desa," JISIP J. Ilmu Sos. dan Ilmu Polit., vol. 6, no. 3, p. 72, 2017, [Online]. Available: www.publikasi.unitri.ac.id.

[10] A. Haris, "Pengaruh penatagunaan tanah terhadap keberhasilan pembangunan infrastruktur dan ekonomi," Bappenas, pp. 1-9, 2009.

[11] U. H. Humaira and J. Nugraha, "Analysis of Factors Affecting the Human Development Index in West Kalimantan Province using Data Panel Data Regression," J. Eksakta, vol. 18, no. 2, pp. 97-105, 2018, doi: 10.20885/eksakta.vol18.iss2.art2.

[12] H. Atmaja and K. Mahalli, "Pengaruh Peningkatan Infrastruktur Terhadap Pertumbuhan Ekonomi Di Kota Sibolga," J. Ekon. dan Keuang., vol. 3, no. 4, p. 14847, 2015.

[13] I. S. Lestari, "Faktor-Faktor Yang Mempengaruhi Pembangunan Infrastruktur (Jalan Dan Jembatan) Di Kecamatan Kampar Kiri Hulu Kabupaten Kampar Tahun 2011 - 2013," vol. 3, no. 1, pp. 1-13, 2015.

[14] Y. Sarwono, "Pengertian Dasar Structural Equation Modeling (SEM)," J. Ilm. Manaj. Bisnis Ukrida, vol. 10, no. 3, pp. 173-182, 2010.

[15] Ririn Widiyasari and Mutiarani, "Penggunaan metode structural equation modelling untuk analisis faktor yang mempengaruhi motivasi belajar mahasiswa fip umj," J. Pendidik. Mat. dan Mat., vol. 3, no. 2, pp. 147-160, 2017.

[16] M. Waluyo, "Mudah Cepat Tepat Penggunaan Tools Amos Dalam Aplikasi (SEM)," UPN Jatim, p. $126,2016$. 